\title{
EXPENDITURE ON PUBLIC SERVICES IN THE COUNTRIES OF THE EUROPEAN UNION. DETERMINANTS OF FISCAL POLICY AND PUBLIC GOVERNANCE
}

JOANNA STAWSKA, ${ }^{1}$ IRENEUSZ JAŹWIŃSKI, ${ }^{2}$ PAULO REIS MOURAO, ${ }^{3}$ RAMONA RUPEIKA-APOGA ${ }^{4}$

\footnotetext{
1 University of Lodz, Faculty of Economics and Sociology, POLAND e-mail: joanna.stawska@uni.lodz.pl

${ }^{2}$ University of Szczecin, Faculty of Management and Economics of Services, POLAND e-mail: ijazwinski@wp.pl

${ }^{3}$ University of Minho, Economics and Management School, Braga, PORTUGAL e-mail: paulom@eeg.uminho.pt

${ }^{4}$ University of Latvia, Faculty of Business, Management and Economics, Riga, LATVIA e-mail: ramona.rupeika-apoga@lu.lv
}

RECEIVED
ACCEPTED
JEL
CLASSIFICATION

KEYWORDS fiscal policy, public services, countries of the European Union, public governance

ABSTRACT The aim of the article is to present the General Government expenditure on public services in the European Union countries, including selected aspects of fiscal policy and public governance. In order to achieve this aim, the varius research methods are used. The data used in the study comes from the following databases: Eurostat, OECD, PORDATA. The survey covers the period of 2007-2016. We note that expenditure on public services is an important determinant of fiscal policy and public governance. The originality of the analysis presented in the article is intended to emphasize the importance of GG spending on public services such as health and education spending in the socio-economic development of the country.

\section{Introduction}

Economic policy, including fiscal policy, is an important element of the state's public policy. Decisions taken by economic authorities as part of fiscal policy are reflected in the socio-economic development of the country. The management of income and public expenditure is an important aspect of public governance. On the other hand, good public governance understood as the manner and effects of exercising authority largely contributes to 
the socio-economic development of individual states. To assess socio-economic development, a synthetic measure called the Human Development Index (HDI) is used. In this study, we used the Spearman's rank correlation coefficient to check the strength of correlation between the socio-economic development index HDI and the GG expenditure on public services - health and education (which are an important component of the HDI index).

The aim of the article is to present the General Government (GG) expenditure on public services in the European Union countries, including selected aspects of fiscal policy and public governance. In order to achieve this aim, the variuos research methods are used, including a statistical analysis method. The study was conducted for the EU countries in the period between 2007-2016. The data used in the study comes from the following databases: Eurostat, OECD, PORDATA.

\section{Fiscal policy and public governance in the area of public services}

Fiscal policy is an important part of economic policy (Grzywacz, Jaźwiński, 2007, pp. 7-36, 122-152). Fiscal policy is primarily used to implement the basic tasks of the state. Through the effects of fiscal policy, the state's activity in terms of the level of meeting social needs is also assessed. Thus, fiscal policy can be defined as the government's use of taxation and public expenditure on the aggregate level of public activity using tax tools and public spending (James, Nobes, 1987, p. 305). The effective management of public funds is important in the context of shortages of public funds for the implementation of many public tasks, including the area of public services. The relative size of these shortages of public resources depends on the implemented or prospective program of socio-economic development with a specific role of public intervention and broadly understood social expectations in this area (Małkowska, 2015, p. 533).

In the context of public expenditure management in the economy, the doctrine of New Public Management, which derives from economic theory and is applicable in practice, is of crucial importance. The efficiency of Public Management was influenced by the transition from the administration doctrine based on rigid procedures and political influences (the so-called bureaucratic model) to management based on economic assessment of the effectiveness of operations and the use of market mechanisms (the so-called managerial model) on which the New Public Management is based (Marchewka-Bartkowiak, 2014, p. 1). Therefore, through the absorption of market mechanisms and management methods and techniques used in the private sector by the public sector, as well as through the administration's focus on effectiveness and economic efficiency, there should be some improvement in the quality of management under New Public Management. One of the important elements of the NRP model is the orientation towards public services and more specifically achieving excellence in the process of providing public services (Młodzik, 2015, p. 185).

Kopits and Symansky report that the implementation of, among others, fiscal rules in the Public Management process was related to ensuring the macroeconomic stability of the state and preventing the economy from expanding fiscal policy, which is to a certain extent related to the possibility of achieving long-term sustainable economic development. The fiscal rules should also help to support monetary policy, prevent fiscal expansion between various levels of government and, consequently, increase the credibility of the fiscal policy (Kopits, Symansky, 1998, pp. 5-8). The new Public Management as a different approach to the functioning of the sector, based on indicators, norms and economic size seems to be an appropriate direction in which the management process in the public sector is heading (Stawska, 2015, p. 19). 
A significant modification that improves management in the public sphere is governance understood as public co-management, participatory public management or interactive management. The concept of governance involves the necessity of public entities transferring part of their competences to other entities and refers to cooperation between sectors and the necessity of trusting (Rhodes, 2007, pp. 1243-1264). According to Office for Public Management and the Chartered Institute of Public Finance and Accountancy (2005, p. 5) good governance means focusing on the organisation's purpose and on outcomes for citizens and service users as well as on developing the capacity and capability of the governing body to be effective.

\section{Analysis of changes in expenditure on public services in the countries of the European Union}

In Table 1 the European Union countries are presented according to General Government expenditure on education as percentage of Gross Domestic Product (GDP) in 2007-2016. We note that public expenditure on education in many EU countries has not changed significantly during the period considered.

Table 1. General government expenditure on education as percentage of GDP

\begin{tabular}{|c|c|c|c|c|c|c|c|c|c|c|}
\hline & 2007 & 2008 & 2009 & 2010 & 2011 & 2012 & 2013 & 2014 & 2015 & 2016 \\
\hline Austria & 4.7 & 4.8 & 5.1 & 5,1 & 5,0 & 5.0 & 5.0 & 4.9 & 4.9 & 4.9 \\
\hline Belgium & 5.5 & 5.7 & 6.0 & 6,0 & 6,2 & 6.2 & 6.4 & 6.3 & 6.4 & 6.4 \\
\hline Bulgaria & 3.6 & 4.0 & 4.1 & 3,6 & 3,4 & 3.3 & 3.7 & 4.1 & 4.0 & 3.4 \\
\hline Croatia & 4.9 & 4.8 & 5.1 & 5,6 & 4,9 & 4.9 & 5.1 & 4.8 & 4.8 & 4.8 \\
\hline Cyprus & 5.9 & 6.3 & 6.7 & 6.9 & 6.7 & 6.3 & 6.8 & 6.0 & 6.0 & 6.0 \\
\hline Czechia & 4.7 & 4.7 & 5.1 & 5.1 & 5.1 & 5.0 & 5.1 & 5.1 & 4.9 & 4.5 \\
\hline Denmark & 5.9 & 6.1 & 6.9 & 7.1 & 6.8 & 7.0 & 6.9 & 7.1 & 7.0 & 6.9 \\
\hline Estonia & 5.9 & 6.7 & 7.2 & 6.6 & 6.2 & 6.3 & 6.0 & 5.7 & 6.1 & 5.9 \\
\hline Finland & 5.8 & 5.8 & 6.5 & 6.6 & 6.5 & 6.4 & 6.4 & 6.4 & 6.2 & 6.1 \\
\hline France & 5.3 & 5.4 & 5.7 & 5.6 & 5.5 & 5.5 & 5.5 & 5.5 & 5.5 & 5.4 \\
\hline Germany & 3.9 & 3.9 & 4.3 & 4.4 & 4.3 & 4.2 & 4.3 & 4.2 & 4.2 & 4.2 \\
\hline Greece & 3.6 & 3.8 & 4.1 & 4.1 & 4.4 & 4.5 & 4.6 & 4.3 & 4.3 & 4.3 \\
\hline Hungary & 5.5 & 5.3 & 5.4 & 5.5 & 5.1 & 4.7 & 4.6 & 5.1 & 5.1 & 4.9 \\
\hline Ireland & 4.3 & 4.7 & 4.7 & 4.6 & 5.1 & 4.9 & 4.7 & 4.3 & 3.3 & 3.3 \\
\hline Italy & 4.5 & 4.4 & 4.6 & 4.4 & 4.1 & 4.1 & 4.1 & 4.0 & 4.0 & 3.9 \\
\hline Latvia & 5.6 & 6.3 & 6.7 & 6.2 & 5.9 & 5.7 & 5.7 & 5.9 & 5.9 & 5.5 \\
\hline Lithuania & 5.3 & 6.1 & 7.2 & 6.4 & 6.1 & 5.8 & 5.6 & 5.4 & 5.4 & 5.2 \\
\hline Luxembourg & 4.5 & 4.8 & 5.5 & 5.7 & 5.6 & 5.8 & 5.1 & 4.9 & 4.9 & 4.9 \\
\hline Malta & 5.2 & 5.2 & 5.4 & 5.6 & 5.7 & 5.8 & 5.8 & 5.6 & 5.5 & 5.4 \\
\hline Netherlands & 5.1 & 5.3 & 5.7 & 5.6 & 5.5 & 5.5 & 5.4 & 5.4 & 5.3 & 5.3 \\
\hline Poland & 5.7 & 5.6 & 5.4 & 5.5 & 5.4 & 5.4 & 5.3 & 5.3 & 5.3 & 5.0 \\
\hline Portugal & 6.2 & 6.4 & 7.0 & 7.1 & 6.6 & 5.8 & 5.9 & 5.7 & 5.1 & 4.9 \\
\hline Romania & 3,8 & 4.3 & 3.9 & 3.3 & 4.1 & 3.0 & 2.8 & 3.0 & 3.1 & 3.7 \\
\hline Slovakia & 3,5 & 3.5 & 4.2 & 4.2 & 4.1 & 4.1 & 4.0 & 4.1 & 4.2 & 3.8 \\
\hline Slovenia & 5,9 & 6.1 & 6.6 & 6.5 & 6.4 & 6.4 & 6.5 & 6.0 & 5.5 & 5.6 \\
\hline Spain & 4 & 4.2 & 4.6 & 4.5 & 4.4 & 4.2 & 4.1 & 4.1 & 4.1 & 4.0 \\
\hline Sweden & 6.3 & 6.4 & 6.8 & 6.5 & 6.4 & 6.5 & 6.6 & 6.6 & 6.5 & 6.6 \\
\hline United Kingdom & 5.8 & 6.0 & 6.5 & 6.5 & 6.0 & 5.7 & 5.1 & 5.0 & 4.9 & 4.7 \\
\hline
\end{tabular}

Source: Eurostat (2018) 
During the discussed ten years, the most was spent on education by such countries as: Denmark, Cyprus, Sweden, Slovenia, Belgium, Finland, Estonia and Portugal. In turn, among countries that in 2007-2016 spent relatively less on education are: Romania, Bulgaria, Slovakia, Greece, Germany and Spain. Among the countries that during the discussed period covered the highest GG expenditure on education, four countries out of seven mentioned were characterized by the highest GDP per capita (Denmark, Sweden, Finland and Belgium).The figures presented in Table 1 show that between the EU countries the differences occur in the field of socio-economic development of a given country.

In Table 2 there are figures concerning GG expenditure on health as percentage of GDP in the European Union countries. The level of public spending on health in individual EU countries also did not change significantly in ten years (changes fluctuated around 1 percentage point).

Table 2. General government expenditure on health as percentage of GDP

\begin{tabular}{|c|c|c|c|c|c|c|c|c|c|c|}
\hline & 2007 & 2008 & 2009 & 2010 & 2011 & 212 & 2013 & 2014 & 2015 & 2016 \\
\hline Austria & 7.4 & 7.5 & 7.8 & 7.9 & 7.7 & 7.7 & 7.8 & 7.8 & 7.9 & 8.0 \\
\hline Belgium & 6.7 & 7.2 & 7.7 & 7.7 & 7.6 & 7.9 & 8.0 & 8.1 & 7.6 & 7.4 \\
\hline Bulgaria & 4.0 & 4.4 & 4.0 & 4.4 & 4.2 & 4.4 & 4.5 & 5.5 & 5.5 & 5.0 \\
\hline Croatia & 5.8 & 6.2 & 6.3 & 6.2 & 6.2 & 7.2 & 6.5 & 6.6 & 6.4 & 6.5 \\
\hline Czechia & 6.8 & 6.9 & 7.8 & 7.8 & 7.7 & 7.7 & 7.6 & 7.6 & 7.6 & 7.4 \\
\hline Cyprus & 2.6 & 2.7 & 3.0 & 3.0 & 3.1 & 3.0 & 3.1 & 2.6 & 2.6 & 2.6 \\
\hline Denmark & 7.7 & 7.9 & 8.9 & 8.6 & 8.4 & 8.7 & 8.5 & 8.6 & 8.6 & 8.6 \\
\hline Estonia & 4.3 & 5.1 & 5.5 & 5.3 & 4.9 & 5.0 & 5.0 & 5.2 & 5.5 & 5.3 \\
\hline Finland & 6.6 & 7.0 & 7.9 & 7.9 & 7.8 & 8.2 & 8.3 & 8.3 & 7.3 & 7.2 \\
\hline France & 7.4 & 7.4 & 7.9 & 7.9 & 7.9 & 8.0 & 8.0 & 8.2 & 8.1 & 8.1 \\
\hline Germany & 6.3 & 6.4 & 7.1 & 7.0 & 6.8 & 6.8 & 7.0 & 7.1 & 7.1 & 7.2 \\
\hline Greece & 6 & 6.5 & 6.8 & 6.9 & 6.5 & 5.8 & 5.2 & 4.7 & 4.7 & 4.9 \\
\hline Hungary & 4.9 & 4.9 & 5.2 & 5.0 & 5.1 & 5.1 & 5.0 & 4.8 & 5.2 & 4.8 \\
\hline Ireland & 6.2 & 6.9 & 7.8 & 7.5 & 7.5 & 7.5 & 7.2 & 6.8 & 5.3 & 5.2 \\
\hline Italy & 6.7 & 7.0 & 7.5 & 7.4 & 7.1 & 7.2 & 7.2 & 7.2 & 7.0 & 7.0 \\
\hline Latvia & 4 & 4.3 & 4.6 & 4.2 & 4.1 & 3.9 & 3.7 & 3.8 & 3.8 & 3.7 \\
\hline Lithuania & 5.2 & 5.6 & 6.7 & 6.9 & 6.6 & 5.9 & 5.6 & 5.5 & 5.8 & 5.8 \\
\hline Luxembourg & 4.3 & 4.4 & 5.1 & 4.9 & 4.7 & 4.9 & 5.2 & 4.9 & 4.7 & 4.8 \\
\hline Malta & 5.5 & 5.3 & 5.1 & 5.3 & 5.4 & 5.5 & 5.7 & 5.7 & 5.8 & 5.6 \\
\hline Netherlands & 6.7 & 6.8 & 7.8 & 7.8 & 7.9 & 8.3 & 8.2 & 8.2 & 8.1 & 7.7 \\
\hline Poland & 4.5 & 5.0 & 5.0 & 5.0 & 4.7 & 4.6 & 4.6 & 4.6 & 4.7 & 4.6 \\
\hline Portugal & 7.1 & 7.2 & 7.9 & 7.4 & 6.9 & 6.5 & 6.4 & 6.2 & 6.1 & 5.9 \\
\hline Romania & 3.6 & 3.7 & 4.1 & 4.1 & 4.1 & 3.8 & 4.0 & 4.0 & 4.2 & 4.0 \\
\hline Slovakia & 6.1 & 6.7 & 7.2 & 7.2 & 6.8 & 6.8 & 6.8 & 7.0 & 7.1 & 7.4 \\
\hline Slovenia & 5.8 & 6.1 & 6.8 & 7.0 & 7.1 & 7.1 & 6.8 & 6.5 & 6.7 & 6.7 \\
\hline Spain & 5.7 & 6.0 & 6.8 & 6.6 & 6.5 & 6.2 & 6.2 & 6.1 & 6.2 & 6.0 \\
\hline Sweden & 6.4 & 6.6 & 7.1 & 6.8 & 6.8 & 6.9 & 7.0 & 7.0 & 6.9 & 6.9 \\
\hline United Kingdom & 6.5 & 6.9 & 7.7 & 7.7 & 7.4 & 7.4 & 7.4 & 7.5 & 7.6 & 7.6 \\
\hline
\end{tabular}

Source: Eurostat (2018). 
Among the countries in which the indicator of public expenditure on health in relation to GDP was the highest, we distinguish: Denmark, Belgium, Finland, Austria, the Netherlands, Czechia, Germany, Sweden, Portugal and the United Kingdom. Among these ten countries with the highest GG expenditures on health care in the European Union, eight of them belong to the group of countries with the highest GDP per capita. On the other hand, the countries that have incurred the least public expenditure on health care are: Cyprus, Latvia, Romania, Luxembourg, Hungary and Poland. Among the six countries listed with the lowest GG expenditure on health care, only Luxembourg belongs to the group of countries with the highest GDP per capita in the EU. Therefore, it is possible that GDP per capita is a factor influencing higher GG spending on health care.

\section{Expenditupe on public services and Human Development Index}

In individual EU countries, expenditures on public services affect social and economic development. Expenditure on education and health are basic investments in human capital (Jaźwiński, 2017, pp. 132-134). Social and economic development is mentioned among the most important goals of the state and public policy. Various indices and measures can be used to determine a level of social and economic development, including development of the European Union countries. It is worth drawing attention to the Human Development Index HDI (see: United Nations Development Programme, 2016, pp. 52-53, 198-209). This index is used by the United Nations, including also the United Nations Development Program (UNDP), for international comparisons. Synthetic HDI comprises the following measures (United Nations Development Programme, 2016, p. 198): life expectancy at birth, expected years of schooling, mean years of schooling, gross national income (GNI) per capita. Expected years of schooling and mean years of schooling show educational achievements of the society. It can be adopted that a measure of life expectancy at birth generally illustrates the general health level of society. HDI value equal 1 may mean that the particular country has the best values of all mentioned variables.

It is worth determining the correlation strength between Human Development Index and expenditure on public services (as percentage of GDP) using the Spearman's rank correlation coefficient, which is considered a measure of the linear correlation and determined by the formula (Stanisz, 2006, p. 296):

where:

$$
r_{s}=1-\frac{6 \sum_{i=1}^{n} d_{i}^{2}}{n\left(n^{2}-1\right)},
$$

$d_{i}$ - difference (positive or negative) between the ranks of corresponding features (variables $x_{i}$ and $y_{i}$ ), $n$ - group size.

Table 3 presents the results of the correlation between HDI and GG expenditures on public services (as the sum of public expenditure on education and health). We note that in the analyzed period, the Spearman's rank correlation index indicates a moderate and significant relationship between GG spending on public services and the indicator of social development - HDI in a given country. 
Tahle 3. Analysis of the correlation of Human Development Index and expenditure on public services as percentage of GDP

\begin{tabular}{lcccccccccc}
\hline Years & 2007 & 2008 & 2009 & 2010 & 2011 & 2012 & 2013 & 2014 & 2015 & 2016 \\
\hline Correlation ratio & 0.5004 & 0.5107 & 0.5364 & 0.6032 & 0.6463 & 0.7192 & 0.7248 & 0.6448 & 0.5584 & 0.6051 \\
\hline
\end{tabular}

Source: author's own study based on Eurostat and United Nations Development Programme data.

In the discussed period, GG expenditure on education and health in the EU countries was significantly correlated with the indicator of socio-economic development - HDI. In 2007-2016, the highest value of the correlation coefficient was achieved in 2012-2013, which may indicate that the GG expenditure on public services (health and education) incurred in previous years contributed to the improvement of socio-economic development measured by the synthetic HDI indicator.

Table 4 lists the European Union countries that were characterized by the largest difference in the ranking between public service expenditure and HDI in particular years.

Table 4. Countries of the European Union with the biggest difference in rankings according

to $\mathrm{HDI}$ and expenditure on public services

\begin{tabular}{cl}
\hline Year & \multicolumn{1}{c}{ Countries } \\
\hline 2007 & Portugal, Germany, Luxembourg, Ireland \\
2008 & Portugal, Germany, Luxembourg, Ireland \\
2009 & Portugal, Germany, Lithuania, Luxembourg \\
2010 & Portugal, Germany, Lithuania, Luxembourg \\
2011 & Portugal, Germany, Luxembourg, Lithuania \\
2012 & Germany, Portugal, Luxembourg, Lithuania \\
2013 & Germany, Croatia, Portugal, Luxembourg \\
2014 & Croatia, Ireland, Luxembourg, Germany \\
2015 & Ireland, Luxembourg, Germany, Croatia \\
2016 & Ireland, Croatia, Luxembourg, Germany \\
\hline
\end{tabular}

Source: author's own study based on Eurostat and United Nations Development Programme data.

Countries most frequently appearing in Table 4 are: Germany, Luxembourg, Portugal and Ireland, which may indicate that in these countries public service expenditure is not significantly reflected in socio-economic development. This can also be explained by substituting public expenditure with private expenditure.

\section{Fiscal policy and public governance in the countries of the European Union - selected examples}

This part will present information on fiscal policy in the context of public governance in three selected European Union countries, i.e. Latvia, Poland and Portugal.

Since the restoration of independence, the Latvian economy has undergone significant structural changes, both in the sectoral structure and in the financial and labour markets. Latvia has historically been a country with low tax revenues. Tax-to-GDP ratio shows that between 2006 and 2015 Latvia's revenues from taxes and social contributions were below the EU average by about $10-11 \%$, fluctuating between $28 \%$ and $29 \%$ of GDP (Eurostat data). In the last ten years, Latvia's general government expenditure has, on average, been $9.4 \%$ lower than the 
EU average, but some public services consistently receive higher than average EU funding. For example, public funding for education has consistently been above the EU average levels. However, many public services such as health care and social protection have generally been funded below the EU average levels. In Latvia public funding for education is one of the largest in Europe, however, the quality of education is moderate, with no apparent improvement in trends. The solutions for a better quality of education for the same money can include: optimizing the network of secondary schools and saving budget funds; shift saved funds to teachers' remuneration; improving the model of secondary school management and improving the quality of teaching content.

Eurostat data clearly shows that general government expenditure on health care is low compared to the other EU member states, and even other states from the former Soviet Union economies. The public health care system of Latvia can make efficiency gains although low funding is a serious problem. A recent publication by OECD notes that approximately one-fifth of health spending in OECD countries could be used more efficiently (OECD, 2017). For example, an OECD review of Latvia's health care system suggests that more extensive use of data to improve the provision and quality of services would increase efficiency (OECD, 2016). Similarly, strengthening quality assurance mechanisms, and monitoring adherence to clinical guidelines could also help. However, Latvia's health system has to deliver effective public health measures with a comparatively limited amount of resources. In other words, more funds will have to be allocated to health care in order to improve public health indicators in line with Latvia's overall level of economic development.

In turn, public income in Poland is characterized by a high share of social security contributions and a low share of indirect taxes. The ratio of public finance sector's revenues to GDP was $38.6 \%$ in $2005,40.8 \%$ in 2007 , $38.1 \%$ in 2010 or $39.2 \%$ in 2017. In Poland, public expenditure is characterized by a high share of expenditure on social protection. Public spending on education in Poland is relatively high, including mainly higher education. In Poland, relatively little is spent on health care (including the low level of investment spending) and on general public services (public administration, interest on the public debt) (Sawulski, 2016a). The share of public spending in GDP reached $42.1 \%$ in Poland, in 2014. It was a lower level than the EU and OECD average and lower than the median for all the analysed countries (43.5\%). Also the share of public expenditure in GDP in Poland (4.2 p.p.) was lower than the EU average. However, the financial crisis had a much lower impact on the GG spending in Poland in comparison to other EU and OECD countries (Sawulski, 2016b).

In Poland, public expenditure on education in relation to GDP amounted to $5.9 \%$ and $5.7 \%$ in 2006 and 2007 , and then fell to $5.0 \%$ in 2016. Average public spending on education in the EU in 2016 amounted to $4.7 \%$ of GDP. In the case of public health expenditure, we note that in 2007 these expenditures contributed $4.5 \%$ of GDP, then increased in 2008-2010 to 5\% of GDP. In subsequent years, starting from 2010, public expenditure on health in relation to GDP started to decrease to $4.6 \%$ in 2016 (on average in the EU, public spending on health in 2016 amounted to $7.1 \%$ of GDP). The economic authorities in Poland face many challenges regarding social policy. It should be emphasized that as part of the implementation of social policy, economic authorities should draw on the best European practices, invest in education and take into account global challenges such as the aging of the population and other challenges of globalization.

Although we can speak of a context of "Social Policy" in Portugal before 1974, it was with the Carnation Revolution and the so-called Democratic State (April 25, 1974) that Portugal entered the modern context of social policies. The governance of these social policies was based on a triangle of forces - broadening the reach of social policies to the general population, increasing associated public spending, and entry of complex figures where 
private individuals were called upon to collaborate. The following paragraphs reflect on two of the major pillars on which this modernization of the governance of Portuguese social policies was based: education and health. In 1974, the percentage of public spending on education in Portugal's income was $1.4 \%$ (PORDATA, 2018). As a result of the focus on social policy as well as the other axes, this percentage was $6.2 \%$ in 2007 , reached a maximum of $7.1 \%$ in 2010 and has since decreased to 4.9\% in 2016 (OECD, 2017). This decline - between 2010 and 2016 - coincided with the structural adjustment policies that the Portuguese public accounts suffered due to the presence of the "Troika" of financing entities (IMF/European Commission/European Central Bank). Additional reasons are related to the decrease in a number of children entering the education system (decrease in the number of children in Portugal), as well as a decrease in the value of association contracts (present in private colleges financed by public money) and public universities that became foundations (with own financing).

In terms of results, the extension of social policy in this sector - coupled with other levers of economic development - promoted the positive evolution of certain indicators: - the illiteracy rate increased from $25.7 \%$ (1974) to $5.2 \%$ (2016); - the percentage of the population with complete secondary education increased from $2.8 \%$ to $118.4 \%$ in the same period (reflecting the arrival of immigrant students, mainly from the Lusophone countries); - the percentage of the population with higher education has increased from $11.8 \%$ to $50 \%$ in these four decades. In the same period - after 1974 - the percentage of public spending on health in Portugal's income was $0.2 \%$ (PORDATA, 2018). This percentage increased from $7.1 \%$ in 2007 to reach a maximum of $7.9 \%$ in 2009 . Since then, it has decreased to $5.9 \%$ in 2016. This decline - between 2010 and 2016 - is explained in part by the aforementioned structural adjustment policies. Additional reasons are related to the expansion of the health network in the hands of private groups, the extension of public-private partnerships in the health sector and the change in the state's share of the price of medicines. In terms of results, the extension of social policy in this sector - without forgetting the role of the other levers of economic development - promoted the positive evolution of certain indicators: - the infant mortality rate has risen from 55.5 per thousand (1974) to one of the lowest in the world: 2.7 (2017); - life expectancy increased from 67.1 years to 80.8 years in the same period; - the number of annual deaths because of tuberculosis has decreased from 626 to 194 in the last 44 years.

\section{Conclusions}

As a result of the analysis, we note that GG expenditure on public services, including in particular health and education expenditures, is a significant determinant of fiscal policy, and also they are the main components of the measure of the socio-economic development - Human Development Index. In addition, spending on social services is also an important element of public governance. In this context, striving to conduct a sustainable fiscal policy additionally based on good public governance is reflected in higher indicators of socio-economic development. In the analyzed period, the Spearman's rank correlation index indicates moderate and significant correlation of GG expenditure on education and health in the EU countries with the indicator of social development in individual countries. Thus, the originality of the analysis presented in the article is intended to emphasize the importance of GG spending on public services such as health and education expenditure in the socio-economic development of the country. Particular European Union countries are characterized by various conditions regarding fiscal policy and public governance. 


\section{Acknowledgments}

The article is a part of the research project financed by the National Science Centre, Poland (grant No. 2017/26/D/HS4/00954).

\section{References}

Eurostat (2018). Retrieved from: http://appsso.eurostat.ec.europa.eu/nui/submitViewTableAction.do.

Grzywacz, W., Jaźwiński, I. (2007). Współczesne uwarunkowania i tendencje polityki ekonomicznej. Szczecin: Wydawnictwo Naukowe Uniwersytetu Szczecińskiego.

James, S., Nobes, C. (1987). The Economics of Taxation. Europe: Prentice Hall.

Jaźwiński, I. (2017). Kapitał ludzki w polityce regionalnej. Szczecin: Wydawnictwo Naukowe Uniwersytetu Szczecińskiego.

Kopits, G., Symansky, S. (1998). Fiscal Policy Rules. Washington: IMF Occasional Paper.

Małkowska, R. (2015). Wydatki publiczne na ochronę zdrowia w Polsce po 2000 roku - wybrane problemy dynamiki i struktury zmian. In: J. Ostaszewski (ed.), O nowy ład finansowy w Polsce. Rekomendacje dla animatorów życia gospodarczego (pp. 533-544). Warszawa: Oficyna Wydawnicza Szkoły Głównej Handlowej.

Marchewka-Bartkowiak, K. (2014). Nowe Zarządzanie Publiczne. Infos - Biuro Analiz Sejmowych, 18 (178).

Młodzik, E. (2015). Założenia koncepcji New Public Management. Współczesne Problemy Ekonomiczne, 11, 185-193.

OECD (2016). Reviews of Health Systems: Latvia 2016. Paris: OECD Publishing.

OECD (2017). Tackling Wasteful Spending on Health. Paris: OECD Publishing.

Office for Public Management, The Chartered Institute of Public Finance and Accountancy (2005). The Good Governance Standard for Public Services. London: The Independent Commission on Good Governance in Public Services.

PORDATA (2018). Retrieved from: www.pordata.pt.

Rhodes, R. (2007). Understanding Governance: Ten Years On. Organization Studies, 28 (8), 1243-1264.

Sawulski, J. (2016a). Finanse publiczne w Polsce - diagnoza na tle innych krajów. IBS Policy Paper 04/2016. Retrieved from: http://ibs. org.pl/app/uploads/2016/04/IBS_Policy_Paper_04_2016_pl.pdf.

Sawulski, J. (2016b). Public Finance in Poland - Evolution, Characteristics and Perspectives. IBS Policy Paper 04/2016. Retrieved from: http://ibs.org.pl/app/uploads/2016/04/IBS_Policy_Paper_04_2016_pl.pdf.

Stanisz, A. (2006). Przystępny kurs statystyki z zastosowaniem STATISTICA PL na przykładach z medycyny. Tom 3. Statystyki podstawowe. Kraków: StatSoft Polska.

Stawska, J. (2015). Polityka fiskalna a wzrost gospodarczy w kontekście Nowego Zarządzania Publicznego. Przedsiębiorczość i Zarządzanie, 12 (1), 7-22.

United Nations Development Programme (2016). Human Development Report 2016. Human Development for Everyone. New York.

United Nations Development Programme (2018). Human Development Data. Retrieved from: www.hdr.undp.org/en/data.

Cite this article aS: Stawska, J., Jaźwiński, I., Mourao, P.R., Rupeika-Apoga, R. (2018). Expenditure on public services in the countries of the European Union. Determinants of fiscal policy and public governance. European Journal of Service Management, 4 (28/2), $429-437$. DOI: 10.18276/ejsm.2018.28/2-51. 